Article

\title{
The Metallogenic Setting of the Jiangjiatun Mo Deposit, North China: Constraints from a Combined Zircon U-Pb and Molybdenite Re-Os Isotopic Study
}

\author{
Ming Li ${ }^{1}$, Xin Zhang ${ }^{2}$, Liang Han ${ }^{2}{ }^{\mathbb{D}}$, En-Pu Gong ${ }^{1}$ and Guo-Guang Wang ${ }^{2, *}$ \\ 1 Department of Geology, Northeastern University, Shenyang 110004, China; limingsdse@163.com (M.L.); \\ gongep@mail.neu.edu.cn (E.-P.G.) \\ 2 State Key Laboratory for Mineral Deposits Research, School of Earth Sciences and Engineering, Nanjing \\ University, Nanjing 210023, China; xinzhang@smail.nju.edu.cn (X.Z.); MG1829006@smail.nju.edu.cn (L.H.) \\ * Correspondence: ggwang@nju.edu.cn; Tel.: +86-25-896-808-93
}

Received: 2 November 2019; Accepted: 19 November 2019; Published: 21 November 2019

\begin{abstract}
The Jiangjiatun Mo deposit is a recently discovered molybdenum deposit in the easternmost area of the Yan-Liao metallogenic belt, North China Craton. Quartz vein-type Mo mineralization at Jiangjiatun is associated with the granitic porphyry stock. In this study, we performed a combined zircon $\mathrm{U}-\mathrm{Pb}$ and molybdenite Re-Os dating study on the Jiangjiatun Mo deposit to constrain its mineralization age and metallogenic setting. Laser ablation inductively coupled mass spectrometry (LA-ICP-MS) zircon $\mathrm{U}-\mathrm{Pb}$ analyses suggest that the granitic porphyry was formed during the Late Jurassic, with a weighted mean ${ }^{206} \mathrm{~Pb} /{ }^{238} \mathrm{U}$ age of $154 \pm 1 \mathrm{Ma}(2 \sigma)$. Seven molybdenite samples from the Jiangjiatun deposit yield a ${ }^{187} \mathrm{Re}-{ }^{187} \mathrm{Os}$ isochron age of $157.5 \pm 0.5 \mathrm{Ma}(2 \sigma)$. The discrepancy between the U-Pb and Re-Os ages may be explained (1) by the " 2 sigma" measurement uncertainty, or (2) by the different closure temperature of the Re-Os isotopic system of molybdenite and the $\mathrm{U}-\mathrm{Pb}$ isotopic system of zircon. Even though there is a small difference between the zircon $\mathrm{U}-\mathrm{Pb}$ and molybdenite Re-Os ages, we can clearly identify a Late Jurassic Mo mineralization event at Jiangiiatun in the easternmost area of the Yan-Liao metallogenic belt. The moderate Re concentrations (13 to 73 ppm) in molybdenite from the Jiangjiatun Mo deposit are indicative of the involvement of the mantle materials into the Mo mineralization. The Jiangjiatun Mo deposit is likely the result of the subduction of the paleo-Pacific plate beneath the North China Craton during the Late Jurassic. Combined with the available published regional robust geochronological data, we proposed that the Mo mineralization in the Yan-Liao belt is in good agreement with the tectonic transition from Late Triassic post-collision extensional setting due to the closure of the paleo-Asian ocean to the Yanshanian $\left(\mathrm{J}-\mathrm{K}_{1}\right)$ continental arc setting in response to the subduction of the paleo-Pacific Plate. The study highlights that regional mineralization may provide an excellent constraint on tectonic change.
\end{abstract}

Keywords: tectonic setting; molybdenite Re-Os isotopes; zircon U-Pb age; Jiangjiatun Mo deposit; Yan-Liao Mo metallogenic belt; north China

\section{Introduction}

China contains the most abundant molybdenum resources in the world, with a proven Mo metal reserve of $>25 \mathrm{Mt}$ [1]. The North China Craton (NCC) contains two important molybdenum metallogenic belts, including the Yan-Liao molybdenum metallogenic belt (YLMB) near the northern margin and the Eastern Qinling-Dabie metallogenic belt (EQL-DB) near the southern margin [1-3] (Figure 1A). The Yan-Liao metallogenic belt near the north margin of the NCC contains about 2.34 Mt of Mo reserves [4,5]. The Mo mineralization in the YLMB is believed to experience long-term magmatism 
during the Mesozoic Period, lasting nearly 100 million years [6,7]. The large-scale Mesozoic Mo mineralization in the YLMB was interpreted to be associated with the closure of the Paleo-Asian ocean [5], the subduction of the paleo-Pacific plate [8,9], or post-orogenic extension after the closure of the Mongolia-Okhotsk Ocean [10,11]. Thus, the viewpoints on the tectonic settings of the YLMB remain unclear.

The Jiangjiatun deposit is a recently discovered Mo deposit in the easternmost area of the YLMB in NCC. To date, no geochronological studies have been performed on the Jiangjiatun Mo deposit. In this study, the laser ablation inductively coupled mass spectrometry (LA-ICP-MS) zircon U-Pb dating of the granitic porphyries and Re-Os isotope analysis of molybdenite in the Jiangjiatun molybdenum deposit were performed. The molybdenum mineralization age of the Jiangjiatun deposit is accurately constrained, and then its tectonic setting is discussed. Moreover, the Re contents of the molybdenite are used to explore the mantle-crust interaction process. Furthermore, to compile previously published reliable geochronological data, we tentatively propose the tectonic genetic model for the YLMB.
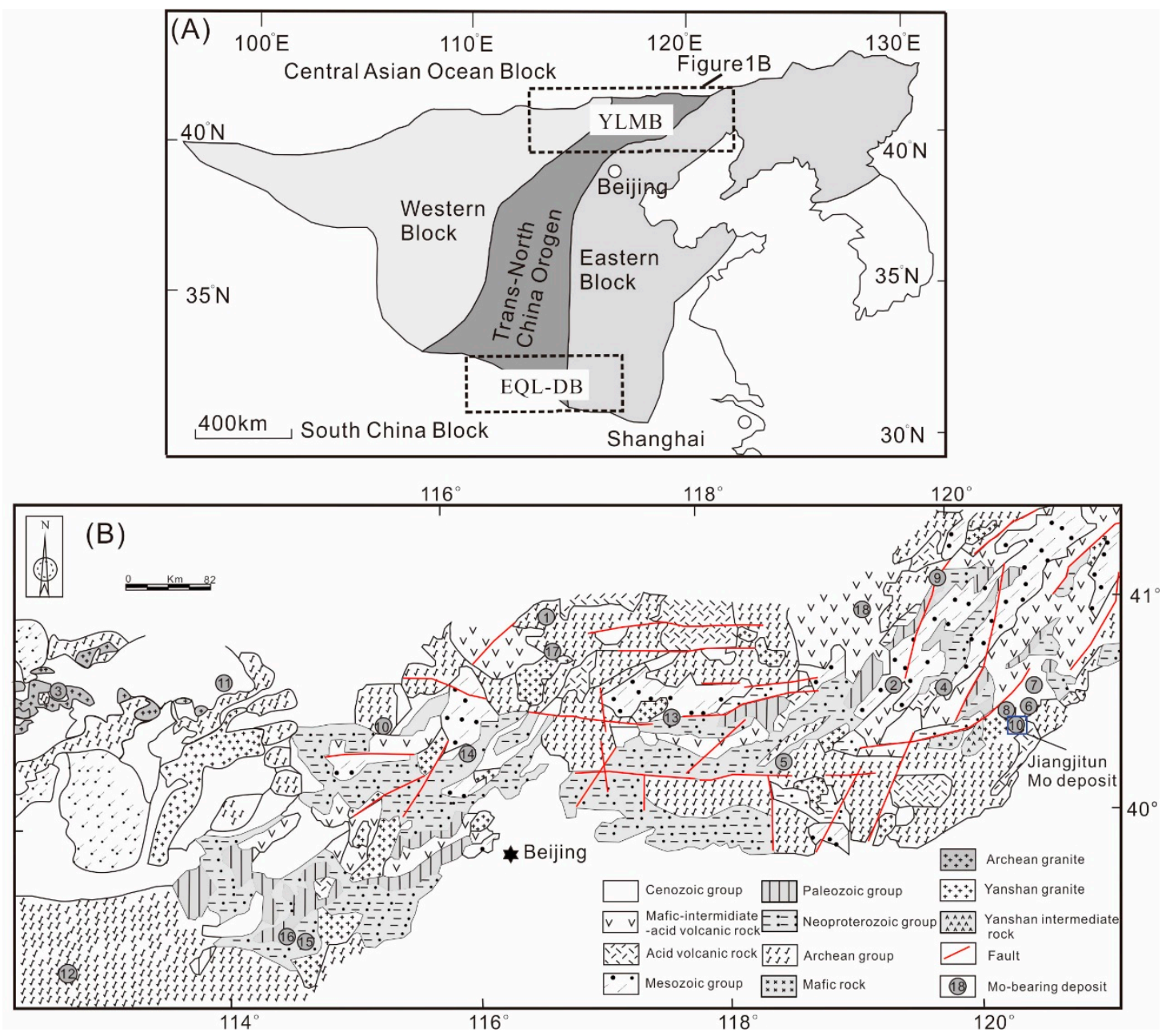

Figure 1. (A) The tectonic units of the North China Craton, including Eastern Block, Ttrans-North China Orogen, and Western Block (modified from Zhao et al., 2012 [12]); (B) schematic geological map showing the Yanshan-Liaoning molybdenum belt on the northern margin of North China Craton (modified from Zeng et al. 2012 and Shu et al., 2016). 1-Sadaigoumen; 2-Hekanzi; 3-Dasuji; 4-Yangmadian; 5-Sibaozi; 6-Yangjiazhangzi; 7-Lanjiagou; 8-Xintaimen; 9-Xiaojiayingzi; 10-Jiangjiatun; 11-Caosiyao; 12-Houyu; 13-Shouwangfen; 14-Dazhuangke; 15-Dawan; 16-Mujicun; 17-Dacaoping; 18-Xiaosigou. Abbreviations: YLMB-Yan-Liao metallogenic belt, EQLDB-East Qinling-Dabie belt. 


\section{Geological Setting}

The basement of the NCC has been divided into the eastern and western blocks by the ca. $1.85 \mathrm{Ga}$ Trans-North China Orogen (Figure 1A) [12-14]. The basement of the NCC was covered by thick sedimentary sequences of Meso-to Neo-Proterozoic and Paleozoic periods [15-17]. The north margin of the NCC was tectonically active, and large-scale magmatism occurred from Triassic to Early Cretaceous periods [4,18-21].

The YLMB in the north margin of the NCC consists of the Archaean basement rocks and the Proterozoic, Paleozoic, and Mesozoic cover sequences from the bottom up [22]. The Paleozoic strata consist of the Cambrian, Ordovician, and Carboniferous limestone, dolomitic limestone, muddy limestone, and shale [23]. The Late Mesozoic strata are distributed in basin, and the simultaneous granites intrude into the regional basement and cover strata [24-26]. This metallogenic belt is featured by the ubiquitous presence of the Late Triassic to Early Cretaceous granites and a group of porphyry-skarn Mo deposits, occurrence and prospects that related to these Late Mesozoic felsic intrusions (Figure 1B) [4,27].

\section{Deposit Geology}

The Jiangjiatun molybdenum deposit is located in the easternmost part of the YLMB. The ore reserve is 160,000 tons, where the average ore grade is $0.09 \%$. The ore-related granite porphyry is the primary magmatic rocks in the deposit, and it hosts the quartz vein-type Mo ore bodies (Figure 2). The essential minerals of the granite porphyry are feldspar, quartz, biotite, and the accessory minerals consist of zircon, apatite, magnetite, and titanite (Figure 3A-F). The strata of the Mesoproterozoic Changcheng and Jixian formations are present in the nearby region, such as the Yangjiazhangzi skarn deposit, but are not exposed at Jiangjiatun. The faults in this deposit are mainly NE-, EW-, and $\mathrm{SN}$-trending, and they are the ore-hosting structures of the Mo ore bodies (Figure 2). In addition, all of these ore bodies are nearly upright.

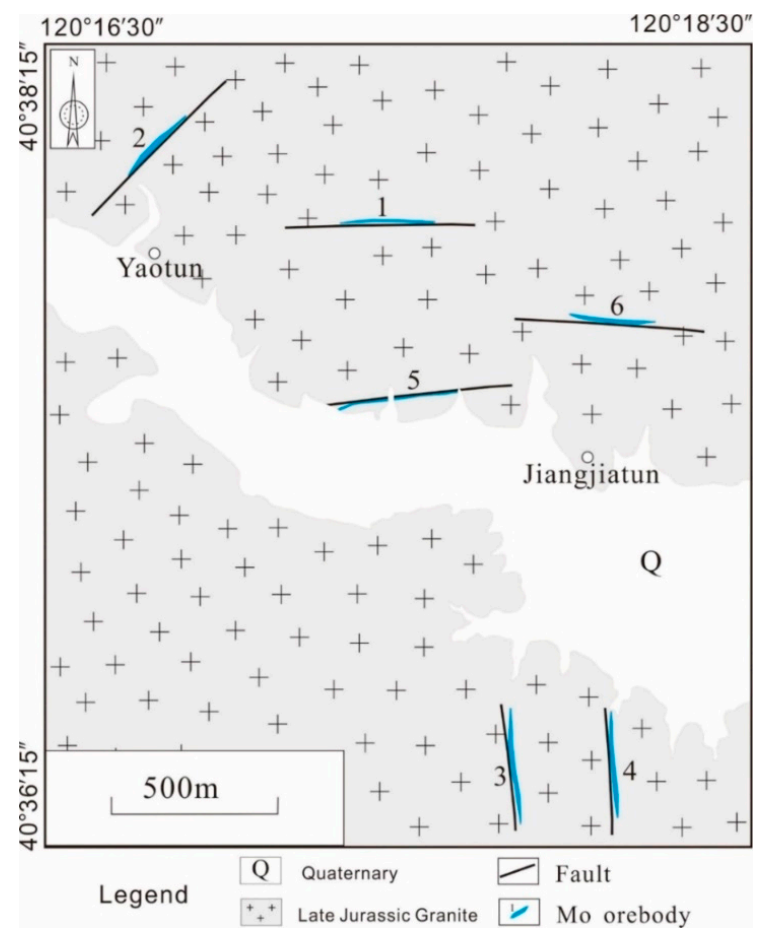

Figure 2. Geological map of the Jiangjiatun molybdenum deposit (242 Brigade Liaoning Province Nuclear Industry Geology Bureau, 2006 [28]). Number 1-6 represents the number of Mo ore bodies at Jiangjiatun. 
There are 6 distinct quartz-molybdenite veins in the Jiangjiatun molybdenum deposit, of which 4 veins strike east-west and northeast in the north part, and 2 veins strike north-south in the south part. The ore bodies are featured by the wide quartz veins, with the width up to $1 \mathrm{~m}$. Molybdenite occurs mostly in the form of thin film and attached to the wall of quartz veins (Figure 3G,H). The wall rock alteration of the Jiangjiatun molybdenum deposit includes potassification, silicification, chloritization, carbonation, and fluoritization. Three alteration zones are recognized from deep to shallow: (1) In the deep level of the ore deposit, potassic alteration is strong and associated with significant mineralization; (2) fluoritization and carbonation mainly occur in the middle level; and (3) carbonation and chloritization are common in the upper level. The principal ore mineral is molybdenite, with minor pyrite, specularite, and chalcopyrite. The gangue minerals are dominated by quartz, K-feldspar, calcite, sericite, chlorite, and fluorite.



Figure 3. (A,B) The quartz-molybdenite veins are present in the underground tunnel of the Jiangjiatun Mo deposit; (C,D) the representative hand samples of granite porphyry at Jiangjiatun; (E,F) the essential minerals of the ore-related granite porphyry at Jiangjiatun under cross-polarized light; $(\mathbf{G}, \mathbf{H})$ molybdenites in the Jiangjiatun Mo deposit. Abbreviations: Mlb—molybdenite, Qtz-quartz, $\mathrm{Pl}$-plagioclase, Kfs-K-feldspar, Cal—calcite, Bi—biotite, and Mus-Muscovite. 


\section{Sampling and Analytical Methods}

\subsection{Zircon $\mathrm{U}-\mathrm{Pb}$ Dating}

Two granite samples were collected from the drill hole. Representative zircons were picked using a binocular optical microscope (United Scope LLC, Irvine, CA, USA) and mounted in epoxy resin disks. The disks were polished and then coated with gold. The microphotographs of zircons were taken in transmitted and reflected light, and cathodoluminescence (CL) was used to examine the internal structure of the analyzed zircons.

LA-ICP-MS zircon isotope analyses were performed using an Agilent 7700x ICP-MS (Agilent Technologies, Santa Clara, CA, USA) equipped with a $193 \mathrm{~nm}$ ArF excimer laser ablation system (ASI RESOnetics, Australian Scientific Instruments Pty Ltd, Canberra, Australia), at the FocuMS Technology company, Nanjing, China. Detailed analytical procedures and the data reduction method were described by Zong et al. [29]. Here, we give a brief summary. A laser beam size of $33 \mu \mathrm{m}$ and an energy density of $3.5 \mathrm{~J} / \mathrm{cm}^{2}$ was chosen with a repetition rate of $6 \mathrm{~Hz}$. The make-up gas, argon (Ar), and the carrier gas, the mixture of argon (Ar) and helium (He), were used by a T-connector before entering the ICP. Nitrogen $\left(\mathrm{N}_{2}\right)$ was added into the central gas flow $(\mathrm{Ar}+\mathrm{He})$ of the Ar plasma to significantly improve precision by declining the detection limit and [30]. During each analysis run, a background acquisition of 20-30 s (gas blank) and a following $50 \mathrm{~s}$ data acquisition were performed. The mass discrimination and $\mathrm{U}-\mathrm{Th}-\mathrm{Pb}$ isotope fractionation was calibrated by the zircon standard 91500 . The recommended U-Th-Pb isotopic ratios used for 91500 following Wiedenbeck et al. (2004) [31]. The precision and accuracy of $\mathrm{U}-\mathrm{Th}-\mathrm{Pb}$ dating were also evaluated by comparison with another zircon standard GJ-1 [32]. An external standard of NIST SRM 610 glass [33] was further analyzed to normalize $\mathrm{U}$, Th, and $\mathrm{Pb}$. Data reduction was performed by the software package ICPMSDataCal (Version 9.0) [34]. Uncertainties of recommended values for the external zircon standard 91500 were propagated into the reduction of the $\mathrm{U}-\mathrm{Pb}$ isotopic results of the zircon samples. The weighted mean values were calculated, and the Concordia diagrams were plotted via Isoplot/Ex (Version 3.0) [35].

\subsection{Molybdenite Re-Os Dating}

Seven molybdenite samples were selected from the ore-bearing quartz vein in the Jiangjiatun Mo deposit, Xincheng, China. Gravity and magnetic separation were first used for crushing the ore samples, and molybdenite grains were handpicked under a binocular optical microscope, with the purity better than 99\%). Re-Os isotope analyses were performed at the Re-Os Laboratory, National Research Center of Geoanalysis, Chinese Academy of Geological Sciences (CAGS), Beijing, China. Detailed chemical procedures of Re-Os analysis performed in this research are described by Du et al. 2004 and Li et al., 2010 [36,37]. The selected pure molybdenite grains were dissolved in $\mathrm{HCl}-\mathrm{HNO}_{3}-\mathrm{H}_{2} \mathrm{O}$ solutions using the Carius tube. The Re-Os isotope was analyzed via an inductively coupled plasma source mass spectrometer TJA X-series ICP-MS manufactured by TJA, Waltham, MA, USA. The analytical reliability was tested by the reference material GBW04436 certified by the JDC standard [36]. The blank during these analyses was approximately $2.9 \pm 0.9 \mathrm{pg}$ for Re and $0.1 \mathrm{pg}$ for Os. The model age of molybdenite was calculated using the following equation and parameters: $t=\left(\ln \left(1+{ }^{187} \mathrm{Os} /{ }^{187} \operatorname{Re}\right)\right) / \lambda$, where $\lambda$ $\left(1.666 \times 10^{-11} \mathrm{yr}^{-1}\right)$ is the decay constant of ${ }^{187} \operatorname{Re}[38]$. The isochron age was calculated, and the iso-chronological age diagram was drawn using Isoplot/Ex (Version 3.0) [35]. Absolute uncertainties of the Re-Os isotopic results were present at the $2 \sigma$ level.

\section{Results}

\subsection{Zircon $\mathrm{U}-\mathrm{Pb}$ Dating}

The euhedral zircon grains were 100-300 $\mu \mathrm{m}$ in length, and the CL images indicated that most of the grains showed oscillatory magmatic zoning (Figure 4). The LA-ICP-MS U-Pb ages data for the two granite porphyry samples are listed in Table 1 and are plotted in Figure 5. The zircon grains showed 
variable $\mathrm{U}(46-602 \mathrm{ppm})$ and Th (179-1146 ppm) concentrations, and Th/U ratios ranged from 0.3 to 1.2 (Table 1).

Twenty-one analyses from sample ZK511-16 yielded a ${ }^{206} \mathrm{~Pb} /{ }^{238} \mathrm{U}$ weighted average age of $154 \pm$ $1 \mathrm{Ma}(2 \sigma, \mathrm{MSWD}=0.96)$. Twenty analyses from sample ZK511-27 presented a ${ }^{206} \mathrm{~Pb} /{ }^{238} \mathrm{U}$ weighted average age of $154 \pm 1 \mathrm{Ma}(2 \sigma, \mathrm{MSWD}=1)$. The LA-ICP-MS U-Pb ages of the zircons from two samples showed that the age of the granite porphyry emplaced at ca. $154 \mathrm{Ma}$ (Figure 5).

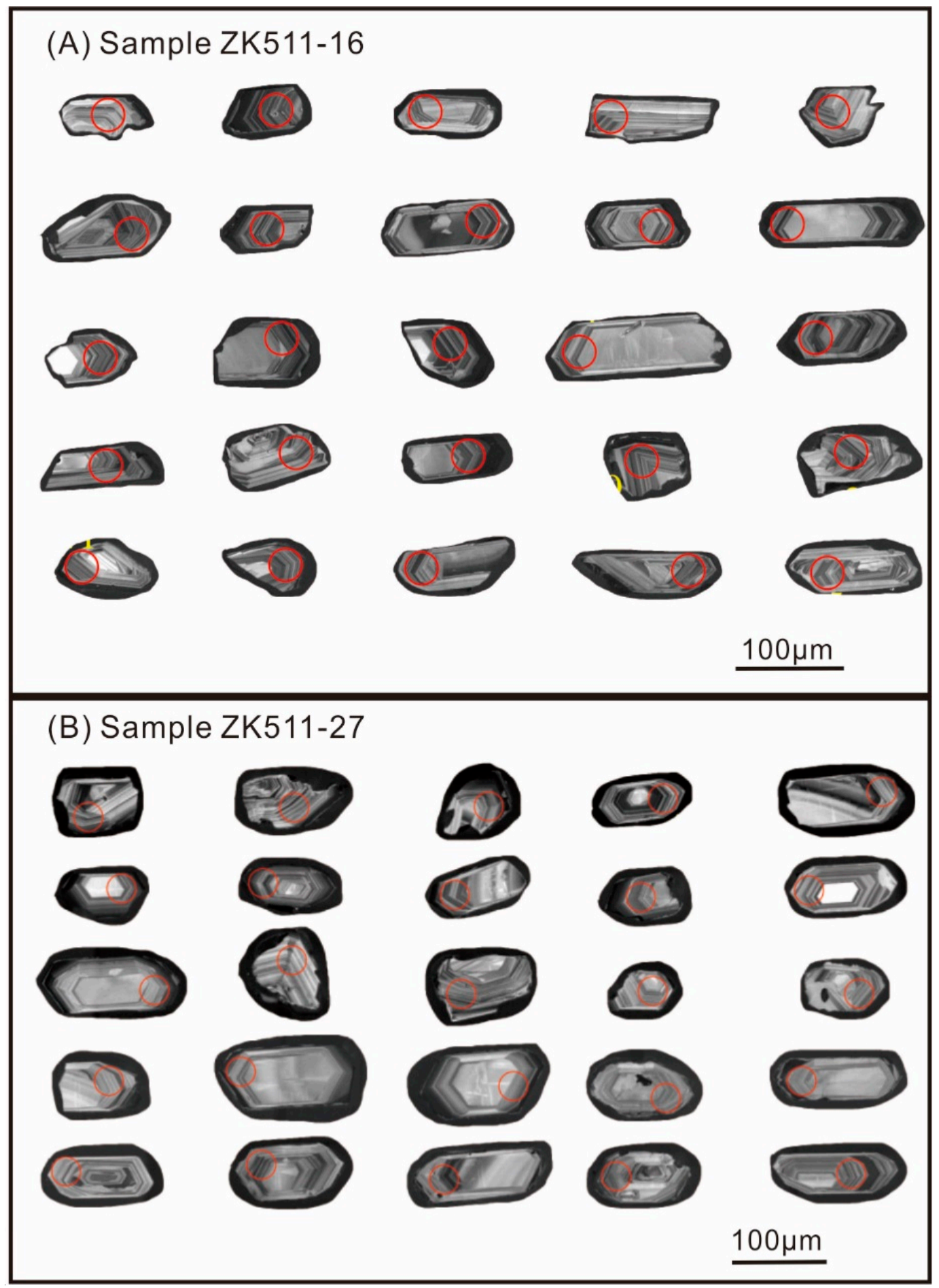

Figure 4. Zircon cathodoluminescence pictures of laser ablation inductively coupled mass (LA-ICP-MS) $\mathrm{U}-\mathrm{Pb}$ dating of granite porphyries in the Jiangjiatun Mo deposit (A: sample No. 511-16 and B: 511-27). 

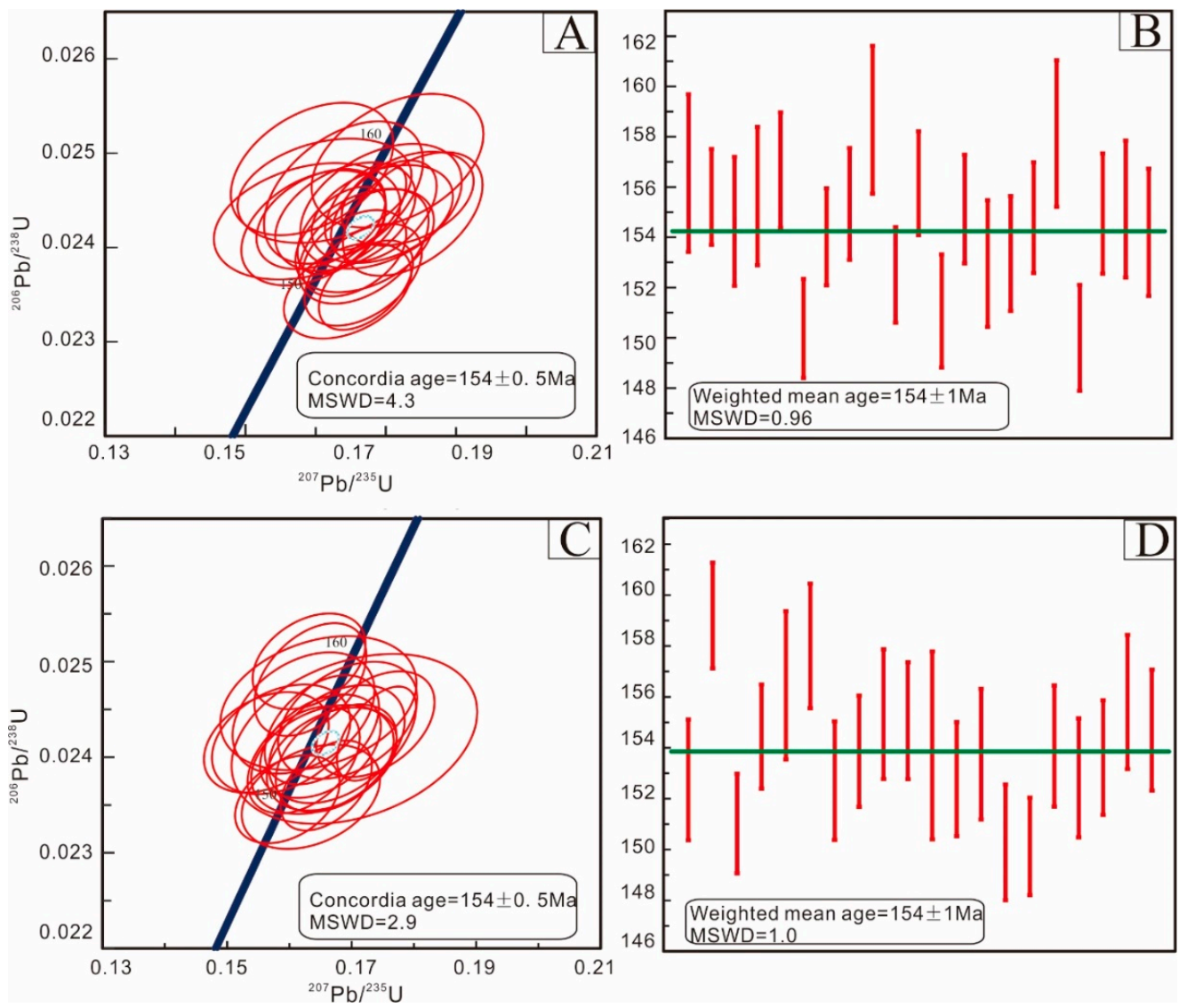

Figure 5. The LA-ICP-MS zircon U-Pb concordant curves and weight mean values for granite porphyries in the Jiangjiatun Mo deposit. (A) The LA-ICP-MS zircon U-Pb concordant curves of sample 511-16; (B) The LA-ICP-MS zircon U-Pb weight mean values of sample 511-16; (C) The LA-ICP-MS zircon U-Pb concordant curves of sample 511-27; (D) The LA-ICP-MS zircon U-Pb weight mean values of sample 511-27.

Table 1. LA-ICP-MS zircon U-Pb dating data of granite porphyries in the Jiangjiatun Mo deposit (sample Number 511-16 and 511-27).

\begin{tabular}{|c|c|c|c|c|c|c|c|c|c|c|c|}
\hline SPOT & Th & $\mathrm{U}$ & $\mathrm{Th} / \mathrm{U}$ & ${ }^{207} \mathrm{~Pb} /{ }^{235} \mathrm{U}$ & $1 \sigma$ & ${ }^{206} \mathrm{~Pb} /{ }^{238} \mathrm{U}$ & $1 \sigma$ & ${ }^{207} \mathrm{~Pb} /{ }^{235} \mathrm{U}$ & $1 \sigma$ & ${ }^{206} \mathrm{~Pb} /{ }^{238} \mathrm{U}$ & $1 \sigma$ \\
\hline \multicolumn{12}{|c|}{ Sample Number 511-16 } \\
\hline 1 & 111 & 179 & 0.62 & 0.16396 & 0.00748 & 0.02458 & 0.0005 & 154 & 7 & 157 & 3 \\
\hline 2 & 698 & 1146 & 0.61 & 0.16712 & 0.00382 & 0.02443 & 0.0003 & 157 & 3 & 156 & 2 \\
\hline 3 & 136 & 191 & 0.71 & 0.15878 & 0.00876 & 0.02428 & 0.00041 & 150 & 8 & 155 & 3 \\
\hline 4 & 131 & 290 & 0.45 & 0.16932 & 0.00759 & 0.02444 & 0.00044 & 159 & 7 & 156 & 3 \\
\hline 5 & 137 & 245 & 0.56 & 0.16127 & 0.00818 & 0.0246 & 0.00036 & 152 & 7 & 157 & 2 \\
\hline 6 & 612 & 723 & 0.85 & 0.16716 & 0.00442 & 0.0236 & 0.00031 & 157 & 4 & 150 & 2 \\
\hline 7 & 547 & 658 & 0.83 & 0.1637 & 0.00416 & 0.02418 & 0.00031 & 154 & 4 & 154 & 2 \\
\hline 8 & 734 & 735 & 1 & 0.16971 & 0.00497 & 0.02439 & 0.00035 & 159 & 4 & 155 & 2 \\
\hline 9 & 161 & 261 & 0.62 & 0.17166 & 0.00808 & 0.02492 & 0.00047 & 161 & 7 & 159 & 3 \\
\hline 10 & 473 & 551 & 0.86 & 0.16555 & 0.00486 & 0.02394 & 0.0003 & 156 & 4 & 153 & 2 \\
\hline 12 & 402 & 534 & 0.75 & 0.1731 & 0.00621 & 0.02452 & 0.00033 & 162 & 5 & 156 & 2 \\
\hline 13 & 413 & 587 & 0.7 & 0.16677 & 0.00551 & 0.02371 & 0.00036 & 157 & 5 & 151 & 2 \\
\hline 14 & 268 & 388 & 0.69 & 0.16949 & 0.00664 & 0.02435 & 0.00034 & 159 & 6 & 155 & 2 \\
\hline 15 & 661 & 770 & 0.86 & 0.16685 & 0.0061 & 0.02401 & 0.0004 & 157 & 5 & 153 & 3 \\
\hline 17 & 138 & 258 & 0.54 & 0.16698 & 0.00651 & 0.02407 & 0.00036 & 157 & 6 & 153 & 2 \\
\hline 18 & 201 & 349 & 0.58 & 0.16075 & 0.00606 & 0.0243 & 0.00035 & 151 & 5 & 155 & 2 \\
\hline 19 & 222 & 342 & 0.65 & 0.15948 & 0.00764 & 0.02483 & 0.00046 & 150 & 7 & 158 & 3 \\
\hline 20 & 211 & 352 & 0.6 & 0.16455 & 0.00599 & 0.02354 & 0.00033 & 155 & 5 & 150 & 2 \\
\hline 22 & 403 & 460 & 0.88 & 0.16422 & 0.0066 & 0.02433 & 0.00038 & 154 & 6 & 155 & 2 \\
\hline 23 & 217 & 615 & 0.35 & 0.17383 & 0.00656 & 0.02436 & 0.00043 & 163 & 6 & 155 & 3 \\
\hline 25 & 218 & 329 & 0.66 & 0.15971 & 0.0068 & 0.02421 & 0.0004 & 150 & 6 & 154 & 3 \\
\hline
\end{tabular}


Table 1. Cont.

\begin{tabular}{|c|c|c|c|c|c|c|c|c|c|c|c|}
\hline SPOT & Th & $\mathrm{U}$ & $\mathrm{Th} / \mathrm{U}$ & ${ }^{207} \mathrm{~Pb} /{ }^{235} \mathrm{U}$ & $1 \sigma$ & ${ }^{206} \mathrm{~Pb} /{ }^{238} \mathrm{U}$ & $1 \sigma$ & ${ }^{207} \mathrm{~Pb} /{ }^{235} \mathrm{U}$ & $1 \sigma$ & ${ }^{206} \mathrm{~Pb} /{ }^{238} \mathrm{U}$ & $1 \sigma$ \\
\hline \multicolumn{12}{|c|}{ Sample Number 511-27 } \\
\hline 1 & 252 & 266 & 0.95 & 0.16532 & 0.00756 & 0.02398 & 0.00038 & 155 & 7 & 153 & 2 \\
\hline 3 & 482 & 407 & 1.18 & 0.16317 & 0.00598 & 0.025 & 0.00033 & 153 & 5 & 159 & 2 \\
\hline 4 & 1153 & 949 & 1.22 & 0.16591 & 0.00485 & 0.0237 & 0.00031 & 156 & 4 & 151 & 2 \\
\hline 5 & 763 & 1102 & 0.69 & 0.17401 & 0.00419 & 0.02425 & 0.00033 & 163 & 4 & 154 & 2 \\
\hline 6 & 91 & 113 & 0.81 & 0.16466 & 0.0104 & 0.02457 & 0.00046 & 155 & 9 & 156 & 3 \\
\hline 8 & 289 & 329 & 0.88 & 0.16337 & 0.00593 & 0.02481 & 0.00039 & 154 & 5 & 158 & 2 \\
\hline 9 & 355 & 308 & 1.15 & 0.16229 & 0.00595 & 0.02397 & 0.00037 & 153 & 5 & 153 & 2 \\
\hline 11 & 376 & 391 & 0.96 & 0.1563 & 0.00662 & 0.02416 & 0.00035 & 147 & 6 & 154 & 2 \\
\hline 12 & 111 & 258 & 0.43 & 0.16936 & 0.00737 & 0.02439 & 0.0004 & 159 & 6 & 155 & 3 \\
\hline 13 & 135 & 323 & 0.42 & 0.17382 & 0.00627 & 0.02435 & 0.00037 & 163 & 5 & 155 & 2 \\
\hline 14 & 76 & 102 & 0.75 & 0.17044 & 0.01302 & 0.02419 & 0.00059 & 160 & 11 & 154 & 4 \\
\hline 16 & 351 & 349 & 1.01 & 0.16682 & 0.00689 & 0.02398 & 0.00036 & 157 & 6 & 153 & 2 \\
\hline 17 & 187 & 254 & 0.73 & 0.16761 & 0.0072 & 0.02414 & 0.00041 & 157 & 6 & 154 & 3 \\
\hline 18 & 218 & 254 & 0.86 & 0.16345 & 0.00733 & 0.02359 & 0.00036 & 154 & 6 & 150 & 2 \\
\hline 19 & 466 & 426 & 1.09 & 0.15968 & 0.00554 & 0.02356 & 0.0003 & 150 & 5 & 150 & 2 \\
\hline 20 & 155 & 207 & 0.75 & 0.15868 & 0.00734 & 0.02419 & 0.00038 & 150 & 6 & 154 & 2 \\
\hline 22 & 422 & 362 & 1.17 & 0.16752 & 0.00641 & 0.02399 & 0.00037 & 157 & 6 & 153 & 2 \\
\hline 23 & 160 & 272 & 0.59 & 0.16499 & 0.0064 & 0.02412 & 0.00036 & 155 & 6 & 154 & 2 \\
\hline 24 & 269 & 288 & 0.93 & 0.16228 & 0.00753 & 0.02446 & 0.00042 & 153 & 7 & 156 & 3 \\
\hline 25 & 275 & 339 & 0.81 & 0.16521 & 0.00605 & 0.02429 & 0.00038 & 155 & 5 & 155 & 2 \\
\hline
\end{tabular}

\subsection{Molybdenite Re-Os Isotopic Dating}

The Re-Os systems of molybdenite had high closure temperature, which avoided the overprint and later hydrothermal or metamorphic effects [39], thus Re-Os dating of molybdenite had become a powerful tool for directly determining the mineralization age. Molybdenite, as the most important economic mineral in the Jiangiiatun deposit, contained high Re and low common Os concentrations (Table 2), which means the method of Re-Os dating of molybdenites can be used to directly and precisely constrain the ore-forming age.

Table 2. Re-Os isotopic data for molybdenites from the Jiangjiatun Mo deposit.

\begin{tabular}{cccccccccc}
\hline Sample & Weight & $\mathbf{R e}$ & $\boldsymbol{\sigma}$ & ${ }^{87} \mathbf{R e}$ & $\boldsymbol{\sigma}$ & ${ }^{\mathbf{1 8 7}} \mathbf{O s}$ & $\boldsymbol{\sigma}$ & Model Age & $\sigma$ \\
\hline & & 28,970 & 326 & 18,208 & 205 & 48.07 & 0.40 & 158.3 & 2.7 \\
DF4-11-2 & 0.03023 & 13,317 & 144 & 8370 & 90 & 22.20 & 0.17 & 159.0 & 2.6 \\
DF4-11-3 & 0.03035 & 23,411 & 192 & 14,714 & 121 & 38.67 & 0.24 & 157.6 & 2.2 \\
DF4-12-1 & 0.03010 & 64,789 & 1006 & 40,721 & 632 & 106.9 & 0.7 & 157.4 & 3.1 \\
DF4-12-2 & 0.03062 & 73,347 & 929 & 46,100 & 584 & 121.8 & 0.7 & 158.4 & 2.7 \\
DF4-10-2 & 0.03077 & 16,560 & 156 & 10,408 & 98 & 27.61 & 0.19 & 159.0 & 2.4 \\
DF4-10-3 & 0.05000 & 17,910 & 184 & 11,257 & 116 & 29.48 & 0.18 & 157.0 & 2.4 \\
\hline
\end{tabular}

Decay constant, $\lambda\left({ }^{187} \mathrm{Re}\right)=1.666 \times 10^{-11} /$ year [3,4]. The uncertainty in each analytical procedure was approximate $1.5 \%$, including the uncertainty of ${ }^{187} \mathrm{Re}$, uncertainty in isotope ratios, and spike calibration. The unit of weight is " $\mathrm{g}$ ", the unit of concentration of Re, ${ }^{187} \mathrm{Re}$, and ${ }^{187} \mathrm{Os}$ is "ng/g"; and the unit of model age is "Ma".

The concentrations of common Re, ${ }^{187} \mathrm{Re}$, and ${ }^{187}$ Os of molybdenites from the Jiangjiatun deposit are shown in Table 2. The Re contents ranged from 13.3 to $73.3 \mu \mathrm{g} / \mathrm{g}$. The ${ }^{187} \mathrm{Os}$ concentrations ranged from 22.2 to $121.8 \mathrm{ng} / \mathrm{g}$ (Table 2). The Re-Os model ages of molybdenite in the Mo-bearing quartz vein ranged from 159 to $157 \mathrm{Ma}$ (Figure 6). These model ages of molybdenites showed a narrow variation range, indicating the consistent age within the measurement uncertainty. In addition, the ${ }^{187} \operatorname{Re}$ and ${ }^{187}$ Os data for molybdenite yield, with a well-constrained isochron age of $157.5 \pm 0.5 \mathrm{Ma}$ (MSWD $=$ $0.72,2 \sigma)$, which was identical to the weighted mean age of $158.1 \pm 1.0 \mathrm{Ma}(\mathrm{MSWD}=0.4,2 \sigma, n=7$ ). 

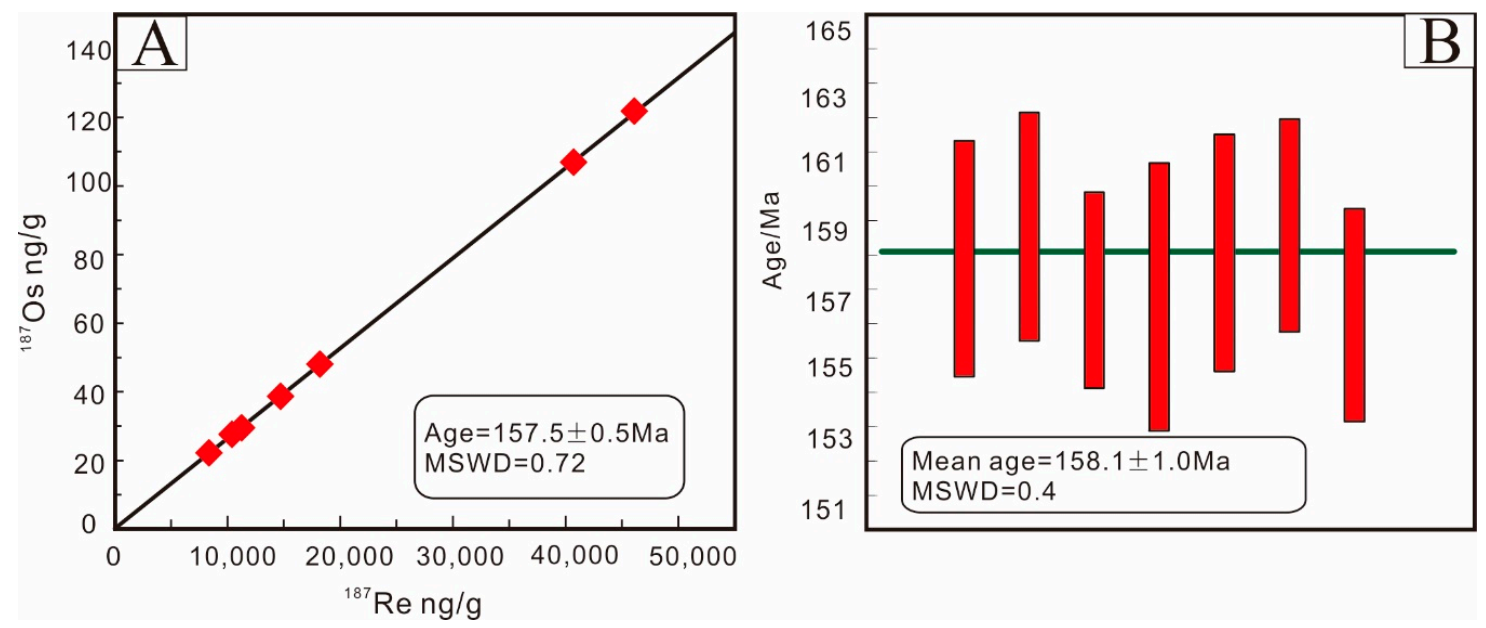

Figure 6. Re-Os isochron (A) and weighted average age (B) of molybdenite from the Jiangjiatun Mo deposit (Red box in Figure 6A and pillar in Figure 6B represents analytical sample of molybdenite; Green line in Figure 6B represents the weight mean of the individual molybdenite model ages).

\section{Discussion}

\subsection{Timing of Mo Mineralization at Jiangjiatun}

The LA-ICP-Ms zircon U-Pb dating results demonstrate that the granite porphyry was emplaced at $154 \pm 1 \mathrm{Ma}$ (Figure 5), suggesting that the ore-related magmatism in the Jiangiiatun deposit occurred during the Late Jurassic. Seven selected molybdenite samples from the Jiangiiatun deposit obtained Re-Os ages of 159 to $157 \mathrm{Ma}$ (Table 2). In addition, these molybdenite samples from the Jiangjiatun deposit show a well-constrained ${ }^{187} \mathrm{Re}-{ }^{187}$ Os isochron age of $158 \mathrm{Ma}$, which was suggested to represent the age of Mo mineralization (Figure 6). The crystallization age of the granite porphyry is consistent with the mineralization ages constrained using the molybdenite Re-Os method, indicating that the Mo mineralization and coeval granitic magmatism at Jiangjiatun took place during late Jurassic.

The YLMB has undergone multi-stage Late Mesozoic magmatic activities [40,41]. Many scholars have carried out precisely single zircon $\mathrm{U}-\mathrm{Pb}$ and molybdenite $\mathrm{Re}-\mathrm{Os}$ isotopic dating in the metallogenic belt. The available published age data of the Mo deposits in the YLMB were collected, and 3 peaks of Mo mineralization were identified, including the Late Triassic $\left(\mathrm{T}_{3}\right)$, Early Jurassic $\left(\mathrm{J}_{1}\right)$, and Late Middle Jurassic and Early Cretaceous $\left(\mathrm{J}_{2}-\mathrm{K}_{1}\right)$ (Table 3 and Figure 7). The first stage of Mo mineralization and related magmatism (237 Ma to $224 \mathrm{Ma}$ ) occurred along the E-W trending boundary between the Central Asian Ocean Belt (CAOB) and NCC, e.g., Dasuji, Sadaogoumen, and Hekanzi [39,42-44]. The secondary stage of Mo mineralization is featured by a short period ranging from 188 to $183 \mathrm{Ma}$ and a limited area of the easternmost region of the YLMB, e.g., Lanjiagou and Yangjiazhangzi [45-49]. The last stage of Mo mineralization was widely developed in the nearly entire Yan-Liao metallogenic belt and lasted a relatively long time from $166 \mathrm{Ma}$ to $140 \mathrm{Ma}$ [40,50-55]. This study provides the easternmost example of the last stage Mo mineralization, implying that the potential to search for Late Jurassic Mo deposits in the nearby area of the Jiangjiatun Mo deposit.

Table 3. Summary of ages of the Mesozoic Mo deposits in the Yan-Liao metallogenic belt, North China Craton.

\begin{tabular}{cccccc}
\hline No. & Deposit Name & Deposit Type & Host Rocks and Ages (Ma) & $\begin{array}{c}\text { Molybdenite } \\
\text { Re-Os Age (Ma) }\end{array}$ & References \\
\hline 1 & Sadaigoumen & Porphyry Mo & Monzogranite (U-Pb, 227.1 \pm 2.7$)$ & $236.5 \pm 2.2$ \\
2 & Hekanzi & Porphyry Mo-Cu & Biotite-orthoclase granite $(\mathrm{U}-\mathrm{Pb}, 235.3 \pm 1.0)$ & $224.0 \pm 1.3$ & {$[40,42]$} \\
3 & Dasuji & Porphyry Mo & Granite porphyry & {$[44]$} & $223.5 \pm 5.5$ \\
4 & Yangmadian & Porphyry Mo & Granite $(\mathrm{U}-\mathrm{Pb}, 189.3 \pm 3.3)$ & - & {$[43]$} \\
5 & Sibozi & Porphyry Mo-Cu & Granite porphyry $(\mathrm{U}-\mathrm{Pb}, 189.8 \pm 0.7)$ & $187.8 \pm 4.5$ & {$[48]$} \\
\hline
\end{tabular}


Table 3. Cont.

\begin{tabular}{|c|c|c|c|c|c|}
\hline No. & Deposit Name & Deposit Type & Host Rocks and Ages (Ma) & $\begin{array}{c}\text { Molybdenite } \\
\text { Re-Os Age (Ma) }\end{array}$ & References \\
\hline 6 & Yangjiazhangzi & Skarn Mo & Porphyritic granite and granite porphyry & $187.0 \pm 2.0$ & {$[46,47]$} \\
\hline 7 & Lanjiagou & Porphyry Mo & Porphyritic granite $(\mathrm{U}-\mathrm{Pb}, 185.0 \pm 1.8)$ & $185.6 \pm 1.2$ & [41] \\
\hline 8 & Xintaimen & Porphyry Mo & Granite porphyry $(\mathrm{U}-\mathrm{Pb}, 181 \pm 2)$ & $183.0 \pm 3.0$ & [56] \\
\hline 9 & Xiaojiayingzi & Skarn Mo-Fe & Diorite $(\mathrm{U}-\mathrm{Pb}, 169.9 \pm 1.4)$ & $165.5 \pm 4.6$ & [50] \\
\hline 10 & Jiangjiatun & Quartz vein Mo & Granite porphyry $(\mathrm{U}-\mathrm{Pb}, 1154 \pm 0.5)$ & $158 \pm 1.5$ & This study \\
\hline 11 & Caosiyao & Porphyry Mo & Granite porphyry $(\mathrm{U}-\mathrm{Pb}, 149.8 \pm 2.4)$ & $149.5 \pm 5.3$ & [51] \\
\hline 12 & Houyu & Porphyry Mo & Quartz porphyry & 148.7 & [54] \\
\hline 13 & Shouwangfen & Skarn Cu-Fe-Mo & Granodiorite & $148.0 \pm 4.0$ & [5] \\
\hline 14 & Dazhuangke & Porphyry Mo & Quartz monzonite (U-Pb, $269 \pm 3)$ & $146.4 \pm 3.4$ & {$[5,47]$} \\
\hline 15 & Dawan & Porphyry-skarn Mo & Rhyolite porphyry & $144.4 \pm 7.4$ & {$[5,53]$} \\
\hline 16 & Mujicun & Porphyry Cu-Mo & Porphyry diorite $(\mathrm{U}-\mathrm{Pb}, 144.1 \pm 1.2)$ & $140.3 \pm 3.9$ & [52] \\
\hline 17 & Dacaoping & Porphyry Mo & Granodiorite (U-Pb, $140 \pm 1.5)$ & $140.1 \pm 3.4$ & {$[40,42]$} \\
\hline 18 & Xiaosigou & Porphyry $\mathrm{Cu}-\mathrm{Mo}$ & Granite porphyry $(\mathrm{K}-\mathrm{Ar}, 122.8 \pm 2.5)$ & - & {$[55]$} \\
\hline
\end{tabular}

\section{CAOB}
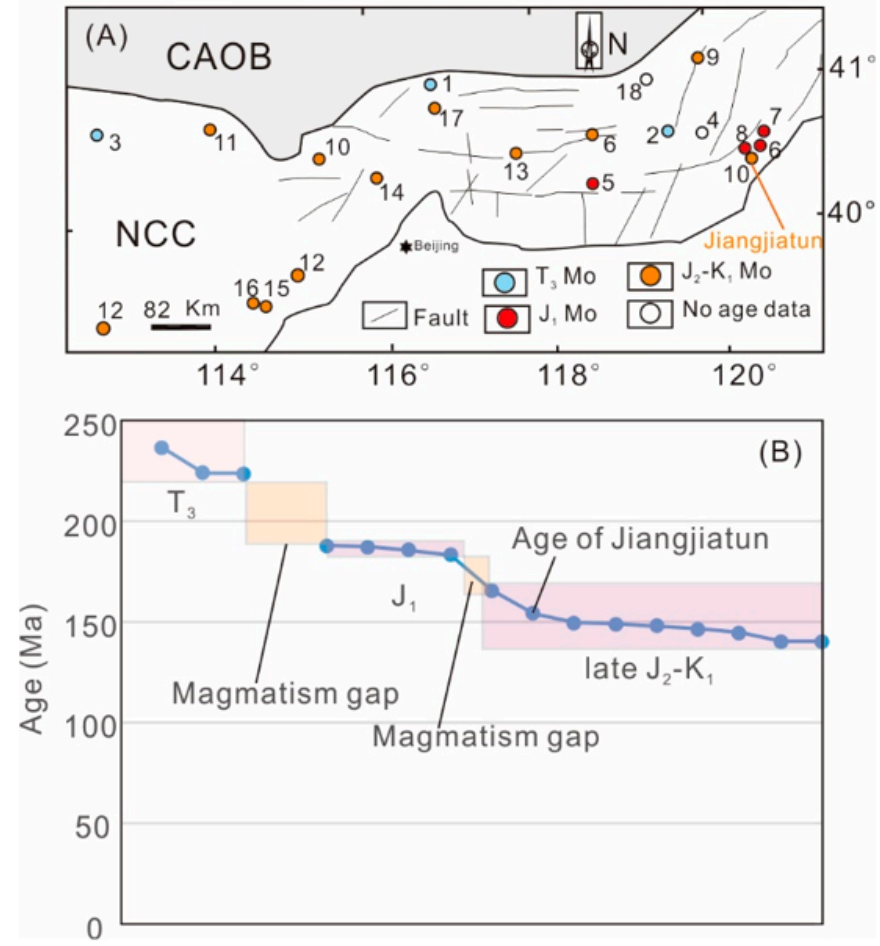

Figure 7. The summary of ages of the Mesozoic Mo deposits in the Yan-Liao metallogenic belt (YLMB), North China craton. Two age gaps of magmatism are identified in this area during Mesozoic. (A) The spatial distribution of the Mo deposits in the YLMB; (B) The comparative age diagrams of the Mo mineralization events in the YLMB. Abbreviations: CAOB-Central Asian Ocean Belt, NCC-North China Craton. The meanings of the numbers denoted in the diagram are the same as Figure 1.

\subsection{Crust-Mantle Interaction Process Indicated by Re Concentrations in Molybdenite}

The wide variation of Re concentrations in molybdenite from the porphyry mineral systems likely provides a critical clue for the origin of ore deposits $[57,58]$. The higher concentrations of Re in molybdnites may be explained by the involvement of the mantle contributions such as mantle underplating or mixing of mafic rocks as part of their genesis. By contrast, the molybdenites from ore deposits that are derived from partial melts of pure crustal rocks or organic-poor sedimentary rocks are featured by lower concentrations of Re [57]. For instance, the mantle materials involved porphyry $\mathrm{Cu}-\mathrm{Mo}$ ore systems generally contain high concentrations of Re (up to thousands of ppm), whereas crustal derived porphyry Mo ore systems typically contain low to single digit ppm of Re. 
The concentration of Re in molybdenites is suggested to be the key information to the relative contributions of mantle and crust for the Mo mineralization. Mao et al. (1999) [58] concluded that Re concentrations in molybdenite evidently decline from mantle source through the mixture of mantle and crust, to pure crustal source. The Re concentrations in molybdenites derived from a mantle source is the highest (commonly $>250 \mathrm{ppm}$ ), and decrease in those produced by the mixtures between mantle (most between 10 and 200 ppm) and crust, and become very low in those sourced from the pure crust (most $<10$ ppm) [59]. In this study, the Reconcentraions in the molybdenites from the Jiangjiatun Mo deposit range from $13 \mathrm{ppm}$ to $73 \mathrm{ppm}$. As show in the Figure 8, all of the molybdenite samples are plotted in the field associated of the mixture of mantle and crust. Thus, we tentatively proposed that the molybdenum in the Jiangjiatun deposit comes from the mixture of crust and mantle.

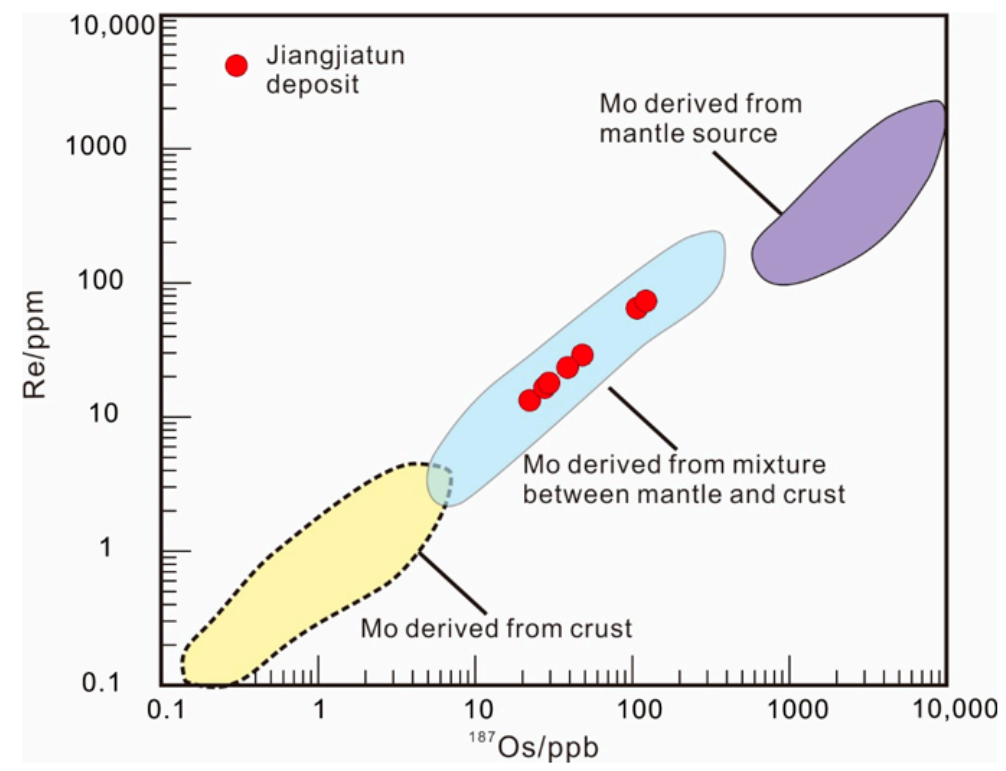

Figure 8. The concentrations of Re vs. ${ }^{187}$ Os diagram (modified from [1]) for the Jiangjiatun Mo deposit.

\subsection{Tectonic Evolution and Metallogenic Setting of the YLMB}

The concentration of Re in molybdenites may provide a crucial constraint on the regional tectonic evolution related to Mo mineralization. We compiled all the available published Re-Os isotopes of molybdenites in the YLMB, and a clear spatial and temporal framework was established (Figure 9 and Table 4). The Re concentration in molybdenites displays a gradually increasing trend from early to late, with the relatively low Re concentration during Late Triassic, the moderate Re concentration in Early Jurassic, and the relatively high Re concentration during Late Jurassic-Early Cretaceous (Figure 9A). The early stage Mo mineralization during Late Triassic featured by low Re concentration took place near the suture zone between CAOB and NCC [40,44,45]. The second stage Mo mineralization during Early Jurassic with moderate Re Early Jurassic occurred locally, only in the east part of the YLMB $[8,20]$. The last stage Mo mineralization during Late Jurassic-Early Cretaceous is widely present in the whole metallogenic belt [52,53] (Figure 9B). The systematical change of Re concentration in molybdenites and the spatial-temporal distribution of the Mo mineralization may outline a tectonic transition history in the YLMB.

The late Triassic Mo mineralization along the boundary between CAOB and the NCC may be explained by the post-extensional setting in response to the closure of the Paleo-Asian ocean $[11,60]$. There is a broad consensus that the final closure of the Paleo-Asian Ocean marked by the Solonker Suture Zone occurred during the Late Permian and Early Triassic [61-63]. During the Late Triassic, the widespread occurrences of alkaline and mafic-ultramafic complexes, rift basins, and metamorphic core complexes indicate that the northern NCC was likely under a post-orogenic extension setting [64-70]. Thus, the Triassic Mo mineralization in the Yan-Liao metallogenic belt occurred along the boundary 
between $\mathrm{CAOB}$ and NCC is inferred to be generated in the post-orogenic extensional setting following the final closure of the Paleo-Asian ocean (Figure 10A).
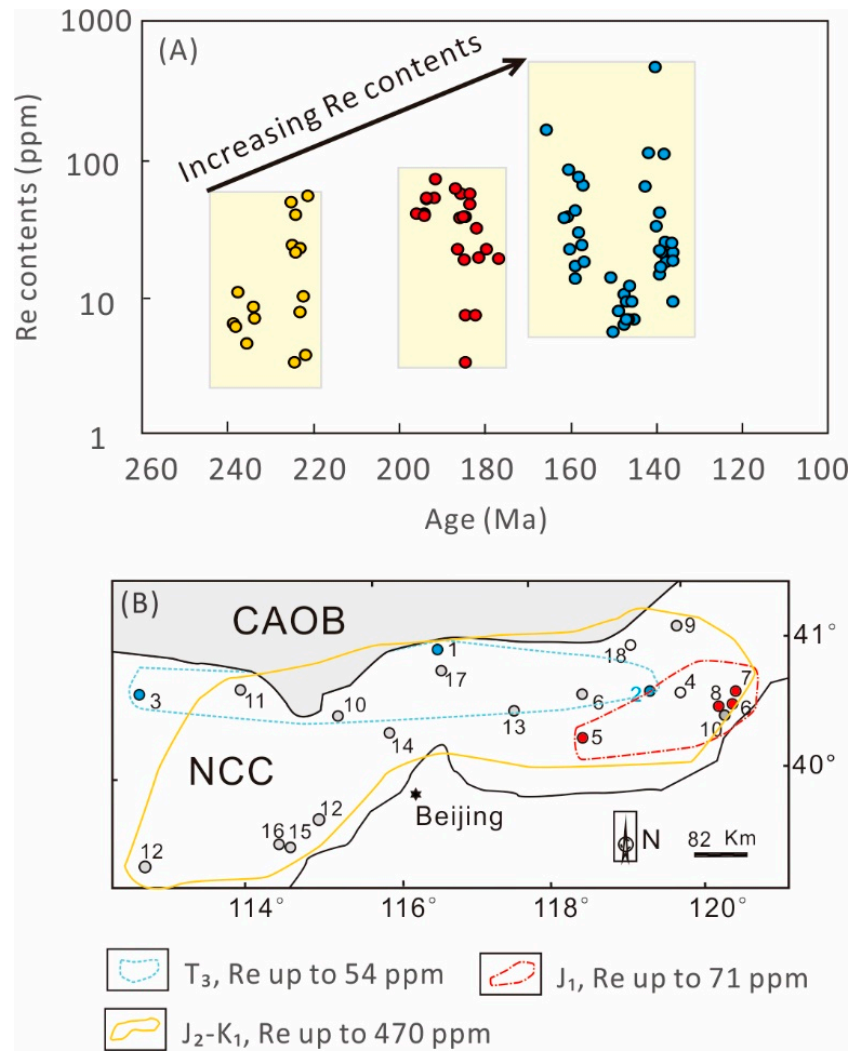

Figure 9. The data of Re concentrations of molybdenite in the Yan-Liao metallogenic belt, North China Craton. (A) The concentrations of Re vs. ages of molydenite diagram of the Yan-Liao metallogenic belt, North China Craton. An obvious increasing trend from Triassic to Yanshanian Period (Jurassic and Cretaceous) is observed. (B) The distribution of Mo deposits and their Re concentrations in molybdenite from the Yan-Liao metallogenic belt, North China Craton. The meanings of the numbers denoted in the diagram are the same as Figure 1.

Table 4. Summary of Re contents and model ages of molybdenite from the Late Mesozoic Mo deposits in the Yan-Liao metallogenic belt, North China Craton.

\begin{tabular}{|c|c|c|c|c|c|}
\hline Deposit Name & Deposit Type & $\operatorname{Re}$ & Model Age (Ma) & Re-Os Age (Ma) & References \\
\hline \multirow{6}{*}{ Sadaigoumen } & \multirow{6}{*}{ Porphyry Mo } & 8.36 & 234.2 & \multirow{6}{*}{$236.5 \pm 2.2$} & \multirow{6}{*}[40,42]{} \\
\hline & & 10.67 & 237.7 & & \\
\hline & & 6.30 & 238.9 & & \\
\hline & & 6.86 & 234 & & \\
\hline & & 5.93 & 238.4 & & \\
\hline & & 4.48 & 235.6 & & \\
\hline \multirow{6}{*}{ Hekanzi } & \multirow{6}{*}{ Porphyry Mo } & 23.4 & 225.1 & \multirow{6}{*}{$224 \pm 1.3$} & \multirow{6}{*}[44]{} \\
\hline & & 39.2 & 224.3 & & \\
\hline & & 54.3 & 221.5 & & \\
\hline & & 22.3 & 223.4 & & \\
\hline & & 20.9 & 224.4 & & \\
\hline & & 48.9 & 225.3 & & \\
\hline \multirow{4}{*}{ Dasuji } & \multirow{4}{*}{ Porphyry Mo } & 3.70 & 222.1 & \multirow{4}{*}{$222.5 \pm 3.2$} & \multirow{4}{*}{ [43] } \\
\hline & & 7.61 & 223.4 & & \\
\hline & & 3.26 & 224.6 & & \\
\hline & & 10.0 & 222.5 & & \\
\hline
\end{tabular}


Table 4. Cont.

\begin{tabular}{|c|c|c|c|c|c|}
\hline Deposit Name & Deposit Type & $\operatorname{Re}$ & Model Age (Ma) & Re-Os Age (Ma) & References \\
\hline \multirow{7}{*}{ Sibozi } & \multirow{7}{*}{ Porphyry Mo-Cu } & 51.5 & 193.9 & \multirow{7}{*}{$194.0 \pm 1.0$} & \multirow{7}{*}{ [48] } \\
\hline & & 40.3 & 194.4 & & \\
\hline & & 51.6 & 192.1 & & \\
\hline & & 40.0 & 196 & & \\
\hline & & 38.7 & 194.4 & & \\
\hline & & 71.4 & 191.6 & & \\
\hline & & 52.1 & 193.7 & & \\
\hline \multirow{11}{*}{ Lanjiagou } & \multirow{11}{*}{ Porphyry Mo } & 18.5 & 184.9 & \multirow{6}{*}{$185.5 \pm 1.0$} & \multirow{11}{*}{ [41] } \\
\hline & & 56.1 & 185.7 & & \\
\hline & & 3.29 & 184.8 & & \\
\hline & & 37.7 & 184.6 & & \\
\hline & & 21.8 & 186.6 & & \\
\hline & & 37.2 & 185.9 & & \\
\hline & & 61.3 & 187 & \multirow{5}{*}{$184.7 \pm 1.8$} & \\
\hline & & 31.3 & 182.2 & & \\
\hline & & 55.4 & 183.8 & & \\
\hline & & 37.7 & 185.2 & & \\
\hline & & 46.8 & 183.8 & & \\
\hline \multirow{5}{*}{ Xintaimen } & \multirow{5}{*}{ Porphyry Mo } & 7.25 & 184.6 & \multirow{5}{*}{$183.0 \pm 3.0$} & \multirow{5}{*}{ [56] } \\
\hline & & 7.28 & 182.4 & & \\
\hline & & 18.8 & 176.9 & & \\
\hline & & 19.0 & 181.6 & & \\
\hline & & 22.1 & 179.7 & & \\
\hline \multirow{6}{*}{ Xiaojiayingzi } & \multirow{6}{*}{ Skarn Mo-Fe } & 37.9 & 160.8 & \multirow{6}{*}{$169.9 \pm 1.4$} & \multirow{6}{*}{ [50] } \\
\hline & & 37.1 & 161.8 & & \\
\hline & & 83.7 & 160.6 & & \\
\hline & & 42.4 & 159.1 & & \\
\hline & & 21.8 & 160.4 & & \\
\hline & & 163 & 165.8 & & \\
\hline \multirow{7}{*}{ Jiangjiatun } & \multirow{7}{*}{ Quartz vein type } & 28.97 & 158.3 & & \\
\hline & & 13.32 & 159.0 & & \\
\hline & & 23.41 & 157.6 & & \\
\hline & & 64.79 & 157.4 & $154 \pm 0.5$ & This study \\
\hline & & 73.35 & 158.4 & & \\
\hline & & 16.56 & 159.0 & & \\
\hline & & 17.91 & 157.0 & & \\
\hline & & 6.22 & 147.7 & & \\
\hline & & 10.4 & 147.7 & & \\
\hline & & 7.72 & 149.1 & $149.5 \pm 5.3$ & \\
\hline & & 13.6 & 150.9 & & \\
\hline & & 5.47 & 150.3 & & \\
\hline Caosiyao & Porphyry Mo & 6.70 & 145.5 & & [51] \\
\hline & & 11.9 & 146.5 & & \\
\hline & & 9.06 & 147.3 & & \\
\hline & & 6.74 & 146.6 & $146.5 \pm 0.8$ & \\
\hline & & 9.15 & 145.8 & & \\
\hline & & 6.72 & 147.3 & & \\
\hline & & 9.15 & 136.3 & & \\
\hline & & 17.7 & 137.9 & & \\
\hline Dawan & Pornhyry-skarn Mo & 24.8 & 138.1 & & {$[5,53]$} \\
\hline Dawan & & 21.0 & 136.2 & $138 \pm 2$ & {$[5,53]$} \\
\hline & & 24.3 & 136.5 & & \\
\hline & & 18.1 & 136.2 & & \\
\hline
\end{tabular}


Table 4. Cont.

\begin{tabular}{|c|c|c|c|c|c|}
\hline Deposit Name & Deposit Type & $\operatorname{Re}$ & Model Age (Ma) & Re-Os Age (Ma) & References \\
\hline \multirow{5}{*}{ Mojicun } & \multirow{5}{*}{ Porphyry Cu-Mo } & 40.5 & 139.4 & \multirow{5}{*}{$140 \pm 2.3$} & \multirow{5}{*}[52]{} \\
\hline & & 108 & 138.5 & & \\
\hline & & 63.2 & 142.7 & & \\
\hline & & 110 & 142.1 & & \\
\hline & & 470 & 140.4 & & \\
\hline \multirow{5}{*}{ Dacaoping } & \multirow{5}{*}{ Porphyry Mo } & 14.5 & 139.4 & \multirow{5}{*}{$139.4 \pm 0.9$} & \multirow{5}{*}[40,42]{} \\
\hline & & 32.5 & 140.2 & & \\
\hline & & 16.2 & 139.2 & & \\
\hline & & 20.9 & 138.9 & & \\
\hline & & 21.7 & 139.5 & & \\
\hline
\end{tabular}
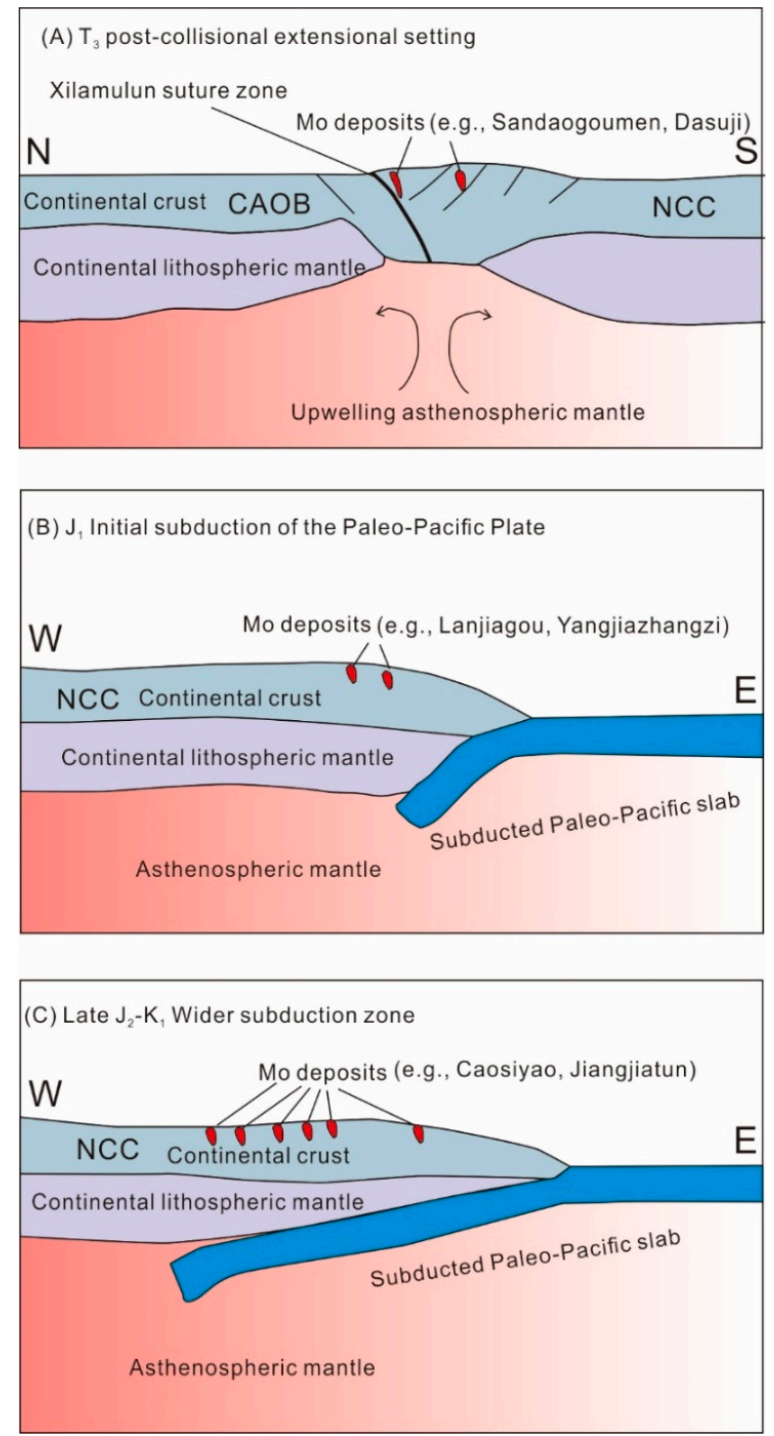

Figure 10. Three stages of genetic model of the Yan-Liao metallogenic belt, North China Craton. (A)The post-collisional setting in response to the closure of the Paleo-Asian ocean during Late Triassic Period; (B) The narrow subduction zone in response to the paleo-Pacific plate during Early Jurassic Period; (C) The wide subduction zone in response to the paleo-Pacific plate during Middle to Early Cretaceous periods. The Jiangjiatun Mo deposit was formed in the beginning period of the last stage of the large scale Mo mineralization. Abbreviations: CAOB-Central Asian Ocean Belt, NCC-North China Craton. 
A short magmatic hiatus (ca. 220 Ma to $190 \mathrm{Ma}$ ) took place (Figure 7) in response to the tectonic switch from the $\mathrm{CAOB}$ tectonic environment to the paleo-Pacific tectonic setting. The subduction of the paleo-Pacific Plate beneath the NCC begun with the widespread formation of the Early Jurassic accretionary complexes along the eastern margin of the Eurasian continent, such as the Heilongjiang Group [71-73]. In addition, the NE-SW striking main tectonic lines of the Late Mesozoic age along the Taihangshan area in NCC are consistent with the spatial and temporal distribution of magmatic belts along the eastern margin of the Eurasian continent, which further supports that the tectonic evolution of the north margin of NCC may be affected by the subduction of the Paleo-pacific Plate [74,75]. Thus, the subduction of the Paleo-Pacific Plate beneath the eastern margin of the NCC initiated during Early Jurassic, and narrow arc-related magmatism was formed at that time (Figure 10B).

The evolution of the Paleo-Pacific Plate has a great influence on the evolution of regional geodynamics (Figure 10C). The paleo-Pacific Plate gradually subducted westward beneath the NCC, and likely reached its climax during the Late Jurassic-Early Cretaceous periods [71,76-78]. The wide subduction zone results in widespread partial melting of the mantle wedge, and then the rising mantle-derived hot mafic magmas likely promote the large-scale melting of the lower to middle continental crust. The large-scale magmatism caused by the subduction of the paleo-Pacific Plate resulted in the widespread Mo deposits in the Yan-Liao metallogenic belt.

\section{Conclusions}

The Jiangjiatun ore-forming granitic porphyry was formed during the Late Jurassic (154 $\pm 1 \mathrm{Ma}$ ), together with the molybdenite ${ }^{187} \mathrm{Re}-{ }^{187}$ Os isochron age of $157.5 \pm 0.5 \mathrm{Ma}$, indicating that the Jiangiatun Mo deposit was formed during Late Jurassic. The intermediate Re concentrations of molybdenite from the Jiangjiatun deposit indicate that the metal Mo is derived from the mixture of continental crust and mantle. The Mo mineralization at Jiangiatun is likely affected by the subduction of the paleo-Pacific Plate. Combining previously published Re-Os isotopic data of molybdenite, we propose a three-stage evolution model that can explain well the regional magmatism, Mo mineralization, and the remarkable change of Re concentrations in molybdenites. A tectonic change from the paleo-Asian Ocean regime to paleo-Pacific regime is revealed by the Mo mineralization in the Yan-Liao metallogenic belt. Hence, the regional mineralization is a potential indicator of tectonic setting.

Author Contributions: M.L., E.-P.G. and G.-G.W.; methodology, M.L., X.Z., L.H. and G.-G.W.; software, M.L., X.Z., L.H. and G.-G.W.; validation, M.L., X.Z., L.H., E.-P.G. and G.-G.W.; formal analysis, M.L., X.Z., and L.H.; investigation, M.L., X.Z., L.H., E.-P.G. and G.-G.W.; resources, M.L., E.-P.G. and G.-G.W.; data curation, M.L., E.-P.G. and G.-G.W.; writing—original draft preparation, M.L., X.Z., L.H., E.-P.G. and G.-G.W.; writing—review and editing, M.L., X.Z., L.H., E.-P.G. and G.-G.W.; visualization, M.L., X.Z., L.H. and G.-G.W.; supervision, E.-P.G. and G.-G.W.; project administration, G.-G.W.; funding acquisition, G.-G.W.

Funding: This work was financially supported by the National Natural Science Foundation of China (Grant No. 40772063).

Acknowledgments: We thank Chao Li, Chinese Academy of Geological Sciences for the Re-Os isotope analyses of molybdenite.

Conflicts of Interest: The authors declare no conflict of interest. The funders had no role in the design of the study; in the collection, analyses, or interpretation of data; in the writing of the manuscript, or in the decision to publish the results.

\section{References}

1. Chen, Y.J.; Pirajno, F.; Li, N.; Deng, X.H. Molybdenum deposits in China. Ore Geol. Rev. 2017, 81, 401-404. [CrossRef]

2. Mao, J.W.; Pirajno, F.; Xiang, J.F.; Gao, J.J.; Ye, H.S.; Li, Y.F.; Guo, B.J. Mesozoic molybdenum deposits in the east Qinling-Dabie orogenic belt: Characteristics and tectonic settings. Ore Geol. Rev. 2011, 43, 264-293. [CrossRef] 
3. Wang, G.G.; Ni, P.; Yu, W.; Chen, H.; Jiang, L.L.; Wang, B.H.; Zhang, H.D.; Li, P.F. Petrogenesis of Early Cretaceous post-collisional granitoids at Shapinggou, Dabie Orogen: Implications for crustal architecture and porphyry Mo mineralization. Lithos 2014, 184-187, 393-415. [CrossRef]

4. Zeng, Q.; Liu, J.; Qin, K.; Fan, H.; Chu, S.; Wang, Y.; Zhou, L. Types, characteristics, and time-space distribution of molybdenum deposits in China. Int. Geol. Rev. 2013, 55, 1311-1358. [CrossRef]

5. Dai, J.Z.; Mao, J.W.; Yang, F.Q.; Ye, H.S.; Zhao, C.S.; Xie, G.Q.; Zhang, C.Q. Geological characteristics and geodynamic background of molybdenum (copper) deposits along Yanshan-Liaoning metallogenic belt on northern margin of North China block. Miner. Depos. 2006, 25, 598-612. (In Chinese)

6. Pirajno, F.; Ernst, R.E.; Borisenko, A.S.; Fedoseev, G.; Naumov, E.A. Intraplate magmatism in Central Asia and China and associated metallogeny. Ore Geol. Rev. 2009, 35, 114-136. [CrossRef]

7. Mao, J.W.; Xie, G.Q.; Zhang, Z.H.; Li, X.F.; Wang, Y.T.; Zhang, C.Q.; Li, Y.F. Mesozoic large-scale metallogenic pulses in North China and corresponding geodynamic settings. Acta Petrol. Sin. 2005, 21, 169-188. (In Chinese)

8. Han, C.; Xiao, W.; Zhao, G.; Sun, M.; Qu, W.; Du, A. A Re-Os study of molybdenites from the Lanjiagou Mo deposit of North China Craton and its geological significance. Gondwana Res. 2009, 16, 264-271. [CrossRef]

9. Chu, S.; Zeng, Q.; Liu, J. Re-Os and U-Pb geochronology of the Songbei porphyry-skarn Mo deposit, North China Craton: Implications for the Early Jurassic tectonic setting in eastern China. J. Geochem. Explor. 2017, 181, 256-269. [CrossRef]

10. Ruan, B.; Lu, X.; Liu, S.; Yang, W. Genesis of Bianjiadayuan Pb-Zn-Ag deposit in Inner Mongolia: Constraints from $\mathrm{U}-\mathrm{Pb}$ dating of zircon and multi-isotope geochemistry. Miner. Depos. 2013, 32, 501-514. (In Chinese)

11. Xu, W.; Wang, F.; Pei, F.; Meng, E.; Tang, J.; Xu, M.; Wang, W. Mesozoic tectonic regimes and regional ore-forming background in NE China: Constraints from spatial and temporal variations of Mesozoic volcanic rock associations. Acta Petrol. Sin. 2013, 29, 339-353. (In Chinese)

12. Zhao, G.; Cawood, P.A. Precambrian geology of China. Precambrian Res. 2012, 222-223, 13-54. [CrossRef]

13. Zhao, Y.; Chen, B.; Zhang, S.; Liu, J.; Hu, J.; Liu, J.; Pei, J. Pre-Yanshanian geological events in the northern margin of the North China Craton and its adjacent areas. Geol. China 2010, 37, 900-915. (In Chinese)

14. Zhao, G.; Wilde, S.A.; Cawood, P.A.; Sun, M. Archean blocks and their boundaries in the North China Craton: Lithological, geochemical, structural and P-T path constraints and tectonic evolution. Precambrian Res. 2001, 107, 45-73. [CrossRef]

15. Zhao, G.; Cawood, P.A.; Li, S.; Wilde, S.A.; Sun, M.; Zhang, J.; He, Y.; Yin, C. Amalgamation of the North China Craton: Key issues and discussion. Precambrian Res. 2012, 222-223, 55-76. [CrossRef]

16. Lu, S.; Zhao, G.; Wang, H.; Hao, G. Precambrian metamorphic basement and sedimentary cover of the North China Craton: A review. Precambrian Res. 2008, 160, 77-93. [CrossRef]

17. Zhao, T.; Deng, X.; Hu, G.; Zhou, Y.; Peng, P.; Zhai, M. The Paleoproterozoic-Mesoproterozoic boundary of the North China Craton and the related geological issues: A review. Acta Petrol. Sin. 2015, 31, 1495-1508. (In Chinese)

18. Wu, F.Y.; Yang, J.H.; Zhang, Y.B.; Liu, X.M. Emplacement ages of the Mesozoic granites in southeastern part of the Western Liaoning Province. Acta Petrol. Sin. 2006, 22, 315-325. (In Chinese)

19. Shu, Q.; Chang, Z.; Lai, Y.; Zhou, Y.; Sun, Y.; Yan, C. Regional metallogeny of Mo-bearing deposits in northeastern China, with new Re-Os dates of porphyry Mo deposits in the Nothern Xilamulun District. Econ. Geol. 2016, 111, 1783-1798. [CrossRef]

20. Xu, X.; Zhang, X.; Zheng, C.; Cui, F.; Gao, Y.; Gao, F. Geochemistry and Chronology Characteristics of the Intrusive Rocks and Its Relationship with Mineralization in Yangjiazhangzi Area, the Western Liaoning Province. Journal of Jilin University. Earth Sci. Ed. 2015, 45, 804-819.

21. Meng, Q.R.; Wei, H.H.; Wu, G.L.; Duan, L. Early Mesozoic tectonic settings of the northern North China craton. Tectonophysics 2014, 611, 155-166. [CrossRef]

22. Hsu, K.J.; Wang, Q.C.; Li, L.; Hao, J. Geologic evolution of the Neimonides-A working hypothesis. Eclogae Geol. Helv. 1991, 84, 1-31.

23. Quan, H. Nonferrous metallic deposits in the northern Hebei Province-Western Liaoning Province area. In Geology and Nonferrous Metallic Deposits in the Northern Margin of the North China Landmass and its Adjacent; Geological Publishing House: Beijing, China, 1994; pp. 383-471. (In Chinese) 
24. Xu, H.; Liu, Y.-Q.; Kuang, H.-W.; Liu, Y.-X.; Peng, N. Jurassic-Cretaceous terrestrial transition red beds in northern North China and their implication on regional paleogeography, paleoecology, and tectonic evolution. Palaeoworld 2017, 26, 403-422. [CrossRef]

25. Liang, S.; Liu, J.; Zhang, Y.; Zhai, F.; Wang, G.; He, G. Liaoxi Hongluoshan-Wuzhishan area molybdenum polymetallic deposits conditions, ore analysis and metallogenic prediction. J. Northwest Univ. Nat. Sci. Ed. 2014, 44, 461-468. (In Chinese)

26. Davis, G.A.; Zheng, Y.; Wang, C.; Darby, B.J.; Zhang, C.; Gehrels, G. Mesozoic tectonic evolution of the Yanshan fold and thrust belt, with emphasis on Hebei and Liaoning provinces, Northern China. In Paleozoic and Mesozoic Tectonic Evolution of Central Asia: From Continental Assembly to Intracontinental Deformation; Hendrix, M.S., Davis, G.A., Eds.; Geological Society of America: Boulder, CO, USA, 2001; pp. 71-197. [CrossRef]

27. Chen, Y.J.; Zhang, C.; Wang, P.; Pirajno, F.; Li, N. The Mo deposits of Northeast China: A powerful indicator of tectonic settings and associated evolutionary trends. Ore Geol. Rev. 2017, 81, 602-640. [CrossRef]

28. Initial Geological Report on the Jiangjiatun Mo Deposit; 242 Brigade Liaoning Province Nuclear Industry Geology Bureau: Jinzhou, China, 2006; unpublished.

29. Zong, K.; Klemd, R.; Yuan, Y.; He, Z.; Guo, J.; Shi, X.; Liu, Y.; Hu, Z.; Zhang, Z. The assembly of Rodinia: The correlation of early Neoproterozoic (ca. $900 \mathrm{Ma}$ ) high-grade metamorphism and continental arc formation in the southern Beishan Orogen, southern Central Asian Orogenic Belt (CAOB). Precambrian Res. 2017, 290, 32-48. [CrossRef]

30. Hu, Z.; Zhang, W.; Liu, Y.; Gao, S.; Li, M.; Zong, K.; Chen, H.; Hu, S. "Wave" signal-smoothing and mercury-removing device for laser ablation quadrupole and multiple collector ICPMS analysis: Application to lead isotope analysis. Anal. Chem. 2015, 87, 1152-1157. [CrossRef]

31. Wiedenbeck, M.; Hanchar, J.M.; Peck, W.H.; Sylvester, P.; Valley, J.; Whitehouse, M.; Kronz, A.; Morishita, Y.; Nasdala, L.; Fiebig, J.; et al. Further characterisation of the 91500 zircon crystal. Geostand. Geoanal. Res. 2004, 28, 9-39. [CrossRef]

32. Jackson, S.E.; Pearson, N.J.; Griffin, W.L.; Belousova, E.A. The application of laser ablation-inductively coupled plasma-mass spectrometry to in situ U-Pb zircon geochronology. Chem. Geol. 2004, 211, 47-69. [CrossRef]

33. Pearce, N.J.G.; Perkins, W.T.; Westgate, J.A.; Gorton, M.P.; Jackson, S.E.; Neal, C.R.; Chenery, S.P. A Compilation of New and Published Major and Trace Element Data for NIST SRM 610 and NIST SRM 612 Glass Reference Materials. Geostand. Newsl. 1997, 21, 115-144. [CrossRef]

34. Liu, Y.; Gao, S.; Hu, Z.; Gao, C.; Zong, K.; Wang, D. Continental and Oceanic Crust Recycling-induced Melt-Peridotite Interactions in the Trans-North China Orogen: U-Pb Dating, Hf Isotopes and Trace Elements in Zircons from Mantle Xenoliths. J. Petrol. 2010, 51, 537-571. [CrossRef]

35. Ludwig, K.R. User's Manual for Isoplot/Ex, Version 3.00, A Geochronological Toolkit for Microsoft Excel; Berkeley Geochronology Center Special Publication: Berkeley, CA, USA, 2003.

36. Du, A.D.; Wu, S.Q.; Sun, D.Z.; Wang, S.X.; Qu, W.J.; Markey, R.; Stain, H.; Morgan, J.; Malinovskiy, D. Preparation and certification of Re-Os dating reference materials: Molybdenites HLP and JDC. Geostand. Geoanal. Res. 2004, 28, 41-52. [CrossRef]

37. Li, C.; Qu, W.J.; Zhou, L.M.; Du, A.D. Rapid Separation of Osmium by Direct Distillation with Carius Tube. Rock Miner. Anal. 2010, 29, 14-16. (In Chinese)

38. Smoliar, M.I.; Walker, R.J.; Morgan, J.W. Re-Os ages of group IIA, IIIA, IVA, and IVB iron meteorites. Science 1996, 271, 1099-1102. [CrossRef]

39. Stein, H.J.; Markey, R.J.; Morgan, J.W.; Du, A.; Sun, Y. Highly precise and accurate Re-Os ages for molybdenite from the East Qinling molybdenum belt, Shaanxi Province, China. Econ. Geol. 1997, 92, 827-835. [CrossRef]

40. Jiang, S.H.; Liang, Q.L.; Bagas, L. Re-Os ages for molybdenum mineralization in the Fengning region of northern Hebei Province, China: New constraints on the timing of mineralization and geodynamic setting. J. Asian Earth Sci. 2014, 79, 873-883. [CrossRef]

41. Zeng, Q.; Chu, S.; Liu, J.; Sun, S.; Chen, W. Mineralization, alteration, structure, and Re-Os age of the Lanjiagou porphyry Mo deposit, North China Craton. Int. Geol. Rev. 2012, 54, 1145-1160. [CrossRef]

42. Duan, H.C.; Qin, Z.Y.; Lin, X.H.; Zhang, B.H.; Liu, X.W.; Zhang, X.; Guo, P.Z.; Han, F.; Qin, L.; Dai, J.Z. Zircon $\mathrm{U}-\mathrm{Pb}$ ages of intrusive bodies in Dacaoping molybdenum ore district, Fengning County, Hebei Province. Miner. Depos. 2007, 26, 634-642. (In Chinese) 
43. Zhang, T.; Chen, Z.Y.; Xu, L.Q.; Chen, Z.H. The Re-Os Isotopic Dating of Molybdenite from the Dasuji Molybdenum Deposit in Zhuozi County of Inner Mongolia and Its Geological Significance. Rock Miner. Anal. 2009, 28, 279-282. (In Chinese)

44. Liu, Y.; Nie, F.; Fang, J. Isotopic age dating of the alkaline intrusive complex and its related molybdenum polymetallic deposit at Hekanzi, western Liaoning Province. Miner. Depos. 2012, 31, 1326-1336. (In Chinese)

45. Zheng, Y.; Feng, H.; Wu, C.; Gu, L.; Liu, S.; He, K. Influence of crude oil on the genesis of the Lanjiagou porphyry molybdenum deposit, western Liaoning Province, China. Ore Geol. Rev. 2014, 60, 1-13. [CrossRef]

46. Chen, Y.; Zhang, C.; Li, N.; Yang, Y.; Deng, K. Geology of the Mo Deposits in Northeast China. Journal of Jilin University. Earth Sci. Ed. 2012, 42, 1223-1268. (In Chinese)

47. Huang, D.H. Metallochronlogy of molybdenum(-copper) deposits in the North China Craton: Re-Os age of molybdenite and its geological significance. Miner. Depos. 1996, 15, 365-373.

48. Li, Q.; Meng, X.; Yang, F.; Wu, F.; Wang, L.; Hu, H.; Liu, F.; Zhang, Z. Re-Os ages of molybdenite from the Sibozi-Liubozi molybdenum-copper deposit in Qinglong County of Hebei Province and Its Implications for Metallogeny. Geol. China 2012, 39, 1622-1634.

49. Feng, H.; Wu, C.; Zheng, Y.; Gu, L.; Jiang, S.; Sun, H.; Gao, L. Geochronology, Geochemistry and Petrogenic \& Metallogenic Settings of the Yangmadian Porphyry Molybdenum Deposit in the Yanshan-Liaoning Metallogenic Belt, North China. J. Jilin Univ. (Earth Sci. Ed.) 2012, 42, 1711-1729.

50. Dai, J.; Mao, J.; Zhao, C.; Me, G.; Yang, F.; Wang, Y. New U-Pb and Re-Os age data and the geodynamic setting of the Xiaojiayingzi Mo (Fe) deposit, western Liaoning province, Northeastern China. Ore Geol. Rev. 2009, 35, 235-244. [CrossRef]

51. Wu, H.; Zhang, L.; Pirajno, F.; Shu, Q.; Zhang, M.; Zhu, M.; Xiang, P. The Mesozoic Caosiyao giant porphyry Mo deposit in Inner Mongolia, North China and Paleo-Pacific subduction-related magmatism in the northern North China Craton. J. Asian Earth Sci. 2016, 127, 281-299. [CrossRef]

52. Dong, G.; Santosh, M.; Li, S.; Shen, J.; Mo, X.; Scott, S.; Qu, K.; Wang, X. Mesozoic magmatism and metallogenesis associated with the destruction of the North China Craton: Evidence from U-Pb geochronology and stable isotope geochemistry of the Mujicun porphyry Cu-Mo deposit. Ore Geol. Rev. 2013, 53, 434-445. [CrossRef]

53. Song, Y.; Ding, H.Y.; Qu, X.M.; Wang, R.J.; Zhou, W.; Wang, S.Z. Re-Os and U-Pb Geochronology of the Dawan Mo-Zn-Fe Deposit in Northern Taihang Mountains, China. Resour. Geol. 2014, 64, 117-135. [CrossRef]

54. Du, B.; Wei, J.; Wang, Q.; Li, Y.; Liu, G.; Yu, H.; Liu, Y. Discussion on metallogenic setting and time difference between magmatism and mineralization of molybdenum deposits in East China. Miner. Depos. 2010, 29, 935-955.

55. Dai, X.; Peng, X.; Hu, X. Adakite in Xiaosigou porphyry copper-molybdenum deposit, Hebei Province: Age, geochemical characteristics and geological implications. Miner. Depos. 2010, 29, 517-528.

56. Zhang, Z.Z.; Wu, C.Z.; Gu, L.X.; Feng, H.; Zheng, Y.C.; Huang, J.H.; Li, J.; Sun, Y.L. Molybdenite Re-Os dating of Xintaimen molybdenum deposit in Yanshan-Liaoning metallogenic belt, North China. Miner. Depos. 2009, 28, 313-320. (In Chinese)

57. Stein, H.J.; Markey, R.J.; Morgan, J.W.; Hannah, J.L.; Schersten, A. The remarkable Re-Os chronometer in molybdenite: How and why it works. Terra Nova 2001, 13, 479-486. [CrossRef]

58. Mao, J.; Zhang, Z.; Zhang, Z.; Du, A. Re-Os isotopic dating of molybdenites in the Xiaoliugou W (Mo) deposit in the northern Qilian mountains and its geological significance. Geochim. Cosmochim. Acta 1999, 63, 1815-1818. [CrossRef]

59. Mao, J.; Wang, Y.; Lehmann, B.; Yu, J.; Du, A.; Mei, Y.; Li, Y.; Zang, W.; Stein, H.J.; Zhou, T. Molybdenite $\mathrm{Re}-\mathrm{Os}$ and albite ${ }^{40} \mathrm{Ar} /{ }^{39} \mathrm{Ar}$ dating of $\mathrm{Cu}-\mathrm{Au}-\mathrm{Mo}$ and magnetite porphyry systems in the Yangtze River valley and metallogenic implications. Ore Geol. Rev. 2006, 29, 307-324. [CrossRef]

60. Eizenhoefer, P.R.; Zhao, G.; Zhang, J.; Sun, M. Final closure of the Paleo-Asian Ocean along the Solonker Suture Zone: Constraints from geochronological and geochemical data of Permian volcanic and sedimentary rocks. Tectonics 2014, 33, 441-463. [CrossRef]

61. Chen, B.; Jahn, B.M.; Wilde, S.; Xu, B. Two contrasting paleozoic magmatic belts in northern Inner Mongolia, China: Petrogenesis and tectonic implications. Tectonophysics 2000, 328, 157-182. [CrossRef] 
62. Xiao, W.J.; Windley, B.F.; Huang, B.C.; Han, C.M.; Yuan, C.; Chen, H.L.; Sun, M.; Sun, S.; Li, J.L. End-Permian to mid-Triassic termination of the accretionary processes of the southern Altaids: Implications for the geodynamic evolution, Phanerozoic continental growth, and metallogeny of Central Asia. Int. J. Earth Sci. 2009, 98, 1189-1217. [CrossRef]

63. Liu, Y.; Li, W.; Feng, Z.; Wen, Q.; Neubauer, F.; Liang, C. A review of the Paleozoic tectonics in the eastern part of Central Asian Orogenic Belt. Gondwana Res. 2017, 43, 123-148. [CrossRef]

64. Davis, G.A.; Xu, B.; Zheng, Y.D.; Zhang, W.J. Indosinian extension in the Solonker suture zone: The Sonid Zuoqi metamorphic core complex, Inner Mongolia, China. Earth Sci. Front. 2004, 11, 135-144.

65. Ritts, B.D.; Darby, B.J.; Cope, T. Early Jurassic extensional basin formation in the Daqing Shan segment of the Yinshan belt, northern North China Block, Inner Mongolia. Tectonophysics 2001, 339, 239-258. [CrossRef]

66. Zhang, S.H.; Zhao, Y.; Liu, X.C.; Liu, D.Y.; Chen, F.; Xie, L.W.; Chen, H.H. Late Paleozoic to Early Mesozoic mafic-ultramafic complexes from the northern North China Block: Constraints on the composition and evolution of the lithospheric mantle. Lithos 2009, 110, 229-246. [CrossRef]

67. Zhang, S.H.; Zhao, Y.; Ye, H.; Hou, K.J.; Li, C.F. Early Mesozoic alkaline complexes in the northern North China Craton: Implications for cratonic lithospheric destruction. Lithos 2012, 155, 1-18. [CrossRef]

68. Liu, S.; Hu, R.Z.; Gao, S.; Feng, C.X.; Qi, L.; Zhang, H.; Xiao, T.F.; Qi, Y.Q.; Wang, T.; Coulson, I.M. Zircon $\mathrm{U}-\mathrm{Pb}$ geochronology and major, trace elemental and $\mathrm{Sr}-\mathrm{Nd}-\mathrm{Pb}$ isotopic geochemistry of mafic dykes in westernShandong Province, east China: Constraints on their petrogenesis and geo-dynamic significance. Chem. Geol. 2008, 255, 329-345. [CrossRef]

69. Darby, B.J.; Davis, G.A.; Zheng, Y.; Zhang, J.; Wang, X. Evolving geometry of the Huhhot metamorphic core complex, Inner Mongolia. China GSA Abstr. Programs 2001, 33, 32.

70. Graham, S.A.; Hendrix, M.S.; Johnson, C.L.; Badamgarav, D.; Badarch, G.; Amory, J.; Porter, M.; Barsbold, R.; Webb, L.E.; Hacker, B.R. Sedimentary record and tectonic implications of Mesozoic rifting in southeast Mongolia. Geol. Soc. Am. Bull. 2001, 113, 1560-1579. [CrossRef]

71. Xu, C.; Zhang, L.; Shi, H.; Brix, M.R.; Huhma, H.; Chen, L.; Zhang, M.; Zhou, Z. Tracing an Early Jurassic magmatic arc from South to East China Seas. Tectonics 2017, 36, 466-492. [CrossRef]

72. Isozaki, Y. Jurassic accretion tectonics of Japan. Isl. Arc 1997, 6, 25-51. [CrossRef]

73. Wu, F.Y.; Yang, J.H.; Lo, C.H.; Wilde, S.A.; Sun, D.Y.; Jahn, B.M. The Heilongjiang Group: A Jurassic accretionary complex in the Jiamusi Massif at the western Pacific margin of northeastern China. Isl. Arc 2007, 16, 156-172. [CrossRef]

74. Luo, Z.H.; Wei, Y.; Xin, H.T.; Ke, S.; Li, W.T.; Li, D.D.; Huang, J.X. The Mesozoic intraplate orogeny of the Taihang Mountains and the thinning of the continental lithosphere in North China. Earth Sci. Front. 2006, 13, 52-63.

75. Zhang, C.; Li, C.; Deng, H.; Liu, Y.; Liu, L.; Wei, B.; Li, H.; Liu, Z. Mesozoic contraction deformation in the Yanshan and northern Taihang mountains and its implications to the destruction of the North China Craton. Sci. China Earth Sci. 2011, 54, 798-822. [CrossRef]

76. Wang, G.G.; Ni, P.; Zhao, C.; Wang, X.L.; Li, P.; Chen, H.; Zhu, A.D.; Li, L. Spatiotemporal reconstruction of Late Mesozoic silicic large igneous province and related epithermal mineralization in South China: Insights from the Zhilingtou volcanic-intrusive complex. J. Geophys. Res. Solid Earth 2016, 121, 7903-7928. [CrossRef]

77. Wang, G.G.; Ni, P.; Yao, J.; Wang, X.L.; Zhao, K.D.; Zhu, R.Z.; Xu, Y.F.; Pan, J.Y.; Li, L.; Zhang, Y.H. The link between subduction-modified lithosphere and the giant Dexing porphyry copper deposit, South China: Constraints from High-Mg adakitic rocks. Ore Geol. Rev. 2015, 67, 109-126. [CrossRef]

78. Wang, G.G.; Ni, P.; Zhao, K.D.; Wang, X.L.; Liu, J.Q.; Jiang, S.Y.; Chen, H. Petrogenesis of the Middle Jurassic Yinshan volcanic-intrusive complex, SE China: Implications for tectonic evolution and Cu-Au mineralization. Lithos 2012, 150, 135-154. [CrossRef]

(C) 2019 by the authors. Licensee MDPI, Basel, Switzerland. This article is an open access article distributed under the terms and conditions of the Creative Commons Attribution (CC BY) license (http://creativecommons.org/licenses/by/4.0/). 